\title{
Unexploited Efficiencies In Higher Education
}

\author{
Henry C. Eyring, Brigham Young University-Idaho, USA
}

\begin{abstract}
In "Unexploited Efficiencies in Higher Education," Henry C. Eyring, a junior majoring in Economics at Brigham Young University-Idaho, argues that one way that the U.S. can compete globally in college attainment is to decrease cost-per-graduate. He explains how many stakeholders in higher education stand to benefit from unexploited cost-efficiencies. Eyring cites strategies implemented by Brigham Young University-Idaho as examples of ways that institutions of higher education can become more cost-efficient in producing graduates. Administrators at Brigham Young University-Idaho utilize a model called the "Graduate Fishbone" that quantifies the effect of alterations to policy, retention, and instructional delivery at Brigham Young University-Idaho on cost, students served, and annual graduates produced. That model allows analysis of the efficacy of cost-efficiency promoting strategies, and is available electronically from the author upon request. An extended version of this paper with additional charts and explanation is also available electronically from the author upon request.
\end{abstract}

Keywords: college attainment; efficiency; higher education; Fishbone diagram; cost-efficiency; cost-per-graduate; productivity; online education; higher education funding; innovative university; Brigham Young University-Idaho; economies of scale; credit hours

\section{INTRODUCTION}

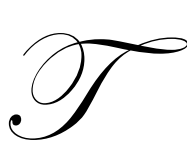

he U.S. system of higher education is facing increasing competition in producing a skilled workforce. Most industrialized countries and some developing ones are outpacing the U.S. in raising their college attainment rates (Auguste, Cota, Jayaram, \& Laboissiere, 2010, p. 7; Barro \& Lee, 2001, p. 27). A number of countries have significantly higher college attainment rates than the U.S. (Lee \& Rawls, 2010, p. 8). A mix of more funds and more efficient use of funds in producing graduates can help America return to pre-eminence in college attainment. Though additional funding and increased cost-efficiency are probably both necessary, increased cost-efficiency would lessen the need for additional funds. For-profit institutions and innovative not-for-profits are demonstrating cost-efficiencies. Research from McKinsey \& Co. showed that if all U.S. institutions of higher education operated at the average cost-per-graduate of the most instructionally cost-efficient quartile of their peer group, the system could decrease cost-per-graduate by about $23 \%$ and produce an extra one million graduates a year by 2020 (Auguste et al, 2010, p. 28).

\section{LITERATURE REVIEW}

In its 2006 report, a commission led by Secretary of Education Margaret Spellings stated, "The commission notes with concern the seemingly inexorable increase in college costs, which have outpaced inflation for the past two decades and have made affordability an ever-growing worry for students, families, and policymakers" (U.S. Department of Education, p. 2). Recent scarcity of funds and the emergence of new technologies have fueled the public discourse on cost-efficiency in higher education.

Many reports on educational cost-efficiency focus on online learning, one of those new technologies. The cost of online high school courses is considerably less than that of the present instructional delivery model (Christensen, Horne, Johnson, 2008, p. 100). As we will see in this paper, through Brigham Young UniversityIdaho's methods of online instruction, similar results have been achieved in the provision of higher education. 
Morris (2008) concluded that while online learning makes economies of scale and scope possible, they do not occur by themselves and are benefits that an administration must aim for when architecting an online learning system. For instance, while highly enrolled online courses create potential scale economies, higher per student support and marketing costs may offset the economic benefit of that type of course delivery (p. 338). A potential economy of scope is the creation of digital learning object repositories, from which an object can be drawn and modified for a given course, but such communication and knowledge sharing does not happen automatically (p. 341).

Taking a broader view of innovation in higher education, White and Glickman (2007) discussed methods of innovation in addition to utilizing technology. Among their suggestions are reducing redundant costs by forming academic consortia and outsourcing ancillary services, and increasing instructional efficiency by equalizing students' education before they arrive at the university (p. 103-104). McKinsey \& Co. considered a variety of innovations in higher education intended to improve cost-efficiency in producing graduates, and included in-depth statistics related to several institutions' progress toward that goal (Auguste et. al, 2010).

This paper focuses on the efficiency-enhancing initiatives of one institution of higher education, Brigham Young University-Idaho, which it is implementing during a period of rapid growth and thereby decreasing the cost of such growth. It also adds to the field of the study of cost-efficiency in higher education by providing a spreadsheet tool used by that university to conceptualize strategic options relating to growth and cost-efficiency. The model is referred to as the "Graduate Fishbone," because it is in the format of a model by a similar name developed in the 1960's by Dr. Kaoru Ishikawa, a leader in the quality movement (McCormick, 2002, p. 227; Boulton \& Pecht, 1995). Almost all higher education institutions will have at least several of the options represented in the Graduate Fishbone, and can use the options that suit them.

This paper draws from a manuscript slated for publication in 2011. That book will provide a historical view of the evolution of higher education in America, initially driven by Harvard and now driven by innovators like Brigham Young University-Idaho, and suggest changes beneficial to many stakeholders in higher education, including individual institutions, students, governments, and other societal stakeholders (Eyring \& Christensen, 2010).

\section{BACKGROUND}

\section{Keywords}

Most of the necessary definitions of terms are included in the body of this paper. Four terms that are not defined in context are Student Credit Hour, or SCH, Full-Time Equivalent, or FTE, and On-Track and Off-Track.

Student Credit Hour: A conventional Student Credit Hour is one hour spent in a class per week. Student Credit Hours can also be referred to simply as "credit hours." Graduating with just 120 credit hours at the end of a four year degree is a commonly discussed goal in higher education. However, only $18 \%$ of full-time, baccalaureate students nationwide earn a four year degree in four years, and so many graduate with more than 120 credit hours (George Mason University, 2004, p. 1).

Full-Time Equivalent: Full-Time Equivalent is a prefix used for faculty and student numbers. Full-Time Equivalent is defined in terms of Student Credit Hours. For instance, if the definition of a Full-Time Equivalent faculty were 12 Student Credit Hours per semester, two faculty members who taught 6 Student Credit Hours per semester would be two faculty members by Headcount, but constitute only one Full-Time Equivalent faculty member.

On-Track and Off-Track: Brigham Young University-Idaho operates on a three semester calendar. Normally, students are only On-Track, or taking courses On-Campus, for two of those three semesters, and for the other semester are considered Off-Track. On-Track students are eligible to register for On-Campus, daytime courses, while Off-Track students typically are not. On-Track students are most similar to what many schools would consider a daytime student with a full course load. 


\section{Current Events}

At the University of Texas on August 9, 2010, President Barrack Obama pledged to stop the U.S.'s competitive slide in college attainment (CNN Wire Staff, 2010). Once a global leader by measures of college attainment, the U.S. has slipped to $12^{\text {th }}$ place in percentage of 25-34 year-olds with a college degree (Lee \& Rawls, 2010). In his speech, President Obama pledged to return the U.S. to the top of that college attainment ranking by 2020, requiring a shift from the current $40 \%$ to about $60 \%$. To increase the percentage of 25-34 year-olds in the U.S. with a college degree, the U.S. system of higher education will need to substantially increase degrees granted per year.

In any production model, the fundamental ways of increasing output are to increase input and to utilize unexploited cost-efficiencies. Many financial supporters of higher education face limits to their ability to contribute. Roughly half of the funding for higher education comes from a mix of government and state funds, including research grants (Miller, 2008; Gorman). The other half includes donations, tuition, and interest on endowments. In the midst of a lingering economic downturn that experts are calling, "the worst recession since the Great Depression," government and individual budgets are tight (Willis, 2009). In 2010 the Federal Government ran a \$1.3 trillion deficit, and some states are facing multi-billion dollar deficits in 2011 (McKinnon, 2010; CNBC, 2010). Higher education is usually among the first programs to go on the chopping block (Ciciora, 2010). Total state spending on higher education fell from $\$ 88.9$ billion in 2008 to $\$ 83.7$ billion in 2010 , a 25 year low in per student spending when adjusted for inflation (de Vise, 2011). For example, after news of a $\$ 50$ million budget cut over the next year and a half, following a $\$ 50$ million cut over the past 4 years, the president of the University of Nevada Las Vegas told faculty, some weeping, that the university would have to become much, "smaller and more expensive" (Holland, 2011). While the federal government has increased support for students by 50\% since President Obama took office, primarily by including Pell grants in economic stimulus packages, such spending may be curtailed by a U.S. House of Representatives that changed control in the 2010 midterm elections, in part due to pledges to rein in spending (Banchero, 2010; GOP, 2010, p. 14). Students and families, many of whom have lost jobs and wealth in the recent recession, are paying tuition that increased annually by 5.6\% adjusted for inflation from 2000-2010 (Banchero, 2010). More higher education funding from any of these sources would, at least in the short-term, further exacerbate a national-savings rate that has dropped to $-3.9 \%$, the lowest since the Great Depression (Salmon, 2010; Karlsson, 2010).

Unexploited cost-efficiencies in the production of graduates provide an opportunity to mitigate the amount of extra funding required for the U.S. to compete in college attainment. Because American colleges and universities are not run like factories, they tend to overlook cost-efficiencies in producing graduates ${ }^{1}$. Evidence of this is the more than $20 \%$ lower cost-per-graduate which the most productive quartile of institutions of higher education in the U.S. are able to achieve (Auguste et al, 2010, p. 28).

If institutions of higher education could utilize such efficiencies, they could pass savings on to students in the form of lower tuition and to government by requiring fewer funds for a given output of graduates. Also, benefits would flow to students who live at home and take online courses while working jobs that might pay more than they would make in their college town. At Brigham Young University-Idaho, in Rexburg, Idaho, $75 \%$ of the cost of attending college is due to transportation, food, and rent, which would all be significantly less for students studying online at home (Eyring \& Christensen, 2010). Another set of stakeholders, donors, would be pleased to know that

\footnotetext{
${ }^{1}$ While a discussion of the causes for institutions of higher education overlooking potential for cost-efficiency in producing graduates is beyond the scope of this article, we ask that the reader accept this statement to facilitate understanding of the rest of the material. In brief, colleges have various outputs and customers who pay for each of those. Some outputs, such as scholarly research, potentially reduce the number of graduates produced by reducing faculty availability for instruction. Most NCAA sports programs require intensive funding that increases the cost-per-graduate produced (Rosner \& Shropshire, 2004, p. 569). Also, many prestigious ranking and classification systems place heavy emphasis on practices such as selectivity in admissions, number of Nobel prizes won, number of scholarly papers published, and whether or not doctoral degrees are awarded (Ranking Methodology, 2010; The Carnegie Foundation; The Princeton Review), which motivate colleges climbing those rankings and classifications to engage in practices that decrease the number of four year degree graduates produced with a given budget.
} 
cost-efficiencies mean that less of their money went to compensating for government budget cuts, allowing more investment in incremental activities such as enhanced student advising.

\section{BRIGHAM YOUNG UNIVERSITY-IDAHO EFFICIENCY INITIATIVES}

Brigham Young University-Idaho is a not-for-profit four year institution that is decreasing cost-pergraduate in ways replicable by other institutions of higher education. The institutions cited as highly productive in the McKinsey \& Co.'s study are a mix of for-profits and not-for-profits and share cost-efficiency strategies with Brigham Young University-Idaho (Auguste et al, 2010, p. 11). In 1997, then president of Brigham Young University-Idaho David A. Bednar challenged his vice presidents to, "think about how to serve more students at an affordable cost" (Eyring \& Christensen, 2010, p. 145). President Bednar implemented some of those changes, and current Brigham Young University-Idaho President Kim B. Clark is rapidly implementing more.

Following is a list of the efficiency-enhancing initiatives that administrators have recently implemented at Brigham Young University-Idaho. These initiatives lead to cost savings by increasing credit hour delivery with a given amount of assets, improving retention, and decreasing the average credit hours of students at graduation.

\section{INSTRUCTIONAL DELIVERY}

\section{Special Session And Evening/Saturday Classes}

- $\quad$ There is a six week-long Special Session between the end of the spring and the start of the fall semester during which students can take courses, increasing building utilization (Brigham Young University-Idaho Academic Administration, 2010). Evening and Saturday classes similarly increase building utilization. Adjunct faculty or full-time faculty teach these courses, but in neither case does this require hiring many, if any, new full-time faculty as traditional growth would.

\section{Online}

BUS

- The Bachelor of University Studies (BUS) is a major for which only 30 of 120 credit hours must be taken in residence at Brigham Young University-Idaho. A Bachelor of University Studies degree's composition is up to the student and the academic advising department, creating flexibility that makes the degree attractive to students. The online component involves adjunct faculty and does not require many physical campus resources (Brigham Young University-Idaho Department of General Studies and University Studies, 2010).

Pathway

- The Pathway program allows students to take courses at off-campus sites. The courses are taught online, but the Church of Jesus Christ of Latter-day Saints allows use of religious meeting houses near "Pathway Sites" for students to meet, take proctored tests, and receive tutoring. Pathway increases the credit hours delivered through existing resources (Eyring \& Christensen, 2010, pp. 192-194). Pathway students cover their cost with tuition of $\$ 65$ per credit hour (Rob Eaton, personal communication, January 21, 2010).

\section{On-Track And Off-Track Online}

- $\quad$ Students of any major who are On-Track or Off-Track at Brigham Young University-Idaho can take many of their classes online, decreasing the need for physical resources and increasing the use of adjunct faculty. Online students can pay a significantly lower tuition than On-Campus students and, unlike On-Campus students, completely cover the cost of their education. The annual cost of On-Campus instruction at Brigham Young University-Idaho is $\$ 8,700$ per student, of which students pay less than half at a rate of about $\$ 120$ a credit hour. Online students can pay $\$ 1,200$ per year, or $\$ 40$ per credit hour, and cover their entire cost (Eyring \& Christensen, 2010, p. 194; Brigham Young University-Idaho Admissions, 2010). 


\section{Transfer, Concurrent Enrollment, And AP Credits}

- Incoming transfer and Advanced Placement credits are almost completely free of cost. Not all credits brought from outside are comparable to Brigham Young University-Idaho required courses, though, so a percentage of these types of credits is lost. Accepting more would further reduce cost-per-graduate. Concurrent Enrollment courses provided through Brigham Young University-Idaho are relatively low-cost because they require fewer campus resources and are usually taught by adjunct faculty or high school faculty. All Concurrent Enrollment courses provided through Brigham Young University-Idaho are convertible to regular credit hours.

\section{POLICIES}

\section{Year-Round Calendar}

- Brigham Young University-Idaho's campus is in operation year-round, with three semesters of equal student and faculty size. Students are admitted to one of three tracks - Spring/Fall, Fall/Winter, Winter/Spring (Eyring \& Christensen, 2010, pp. 162-163). This practice increases credit hour production for a given building and faculty allocation by half of what it would be with a two semester calendar. The increased use of campus and other fixed resources allows Brigham Young University-Idaho to pay faculty members more than peer-institutions while still decreasing its cost of producing a graduate by $32 \%$ (Auguste et al, 2010, p. 14). Brigham Young University-Idaho faculty were not forced to participate in the year-round schedule. They were given a number of options, among which was the choice to maintain their current teaching load and salary. However, over $95 \%$ elected to teach for three full semesters and receive a salary increase (Brigham Young University-Idaho Academic Administration, personal communication, January 24, 2011).

\section{Modular Curriculum}

- $\quad$ Students' changing of majors adds significantly to average credit hours at graduation because credits that are not transferable to the end major are lost. The cost in credit hours of that occurrence is amplified by majors that require many credit hours to graduation and majors that contain a large number of courses unique to the given major. At Brigham Young University-Idaho, interdepartmental task forces are reconstructing majors to reduce those credit losses. To decrease the credit hours to graduation requirement, reconstructed majors allow students who have satisfied their core requirement to select from small collections of related elective courses that prepare them for a specific career. Traditional majors have required students at that point to take a greater number of electives without guidance, which means a longer time to graduation and less focused workplace preparation. To increase modularity, reconstructed majors are built as collections of cross-disciplinary units of courses, rather than individual courses entirely unique to the given major (Eyring \& Christensen, 2010, p. 184).

\section{Retention}

- $\quad$ Credit hours that permanent dropouts take do not contribute to the production of graduates. The Spellings Commission suggests that American higher education institutions are not doing enough to retain students: "Some [students] never complete their degrees at all, at least in part because most colleges and universities don't accept responsibility for making sure that those they admit actually succeed" (U.S. Department of Education, 2006, p. x). Brigham Young University-Idaho's withdrawal rate is 32\% lower than the nation's average (Auguste et al, 2010, p. 13). As part of Brigham Young University-Idaho's effort to increase retention, each student is assigned a faculty advisor, and the advising office has developed a "drag-anddrop" graduation path planning software, which guides students in creating realistic, efficient graduation plans. A student with a declared major can use the software to see all of the courses necessary for graduation on one screen, and then drop each course into a slot in an eight-semester template. The computer program identifies the prerequisites for each course and only allows the courses to be placed in an order in which all prerequisites are satisfied (Eyring \& Christensen, 2010, p. 182). 


\section{No Research-Based Rank}

- $\quad$ At Brigham Young University-Idaho there are no monetary or rank incentives to do scholarly research. Those incentives are present at many universities; most professors expect to spend at least half of their time on research. The average per faculty semester teaching load at leading American universities is 4-6 courses, tapering down to 2-3 (Smith \& Bender, 2008, p. 340). By specializing in teaching, Brigham Young University-Idaho is able to double credit hour delivery for a given faculty size compared to leading universities by requiring full-time professors to typically teach twelve credit hours per semester ( $\mathrm{P}$. Clements, personal communication, November 18, 2010).

\section{INNOVATION AT MANY INSTITUTIONS}

While this study emphasizes Brigham Young University-Idaho as an exemplar of cost-efficiency in higher education, there are many other institutions of higher education that are innovating to meet the needs of students and society. In 2008, over one fourth of U.S. students at the post-secondary level were taking at least one course online, and by 2009 the number taking online had grown by 21\% (Zylberberg, 2010; Allen \& Seaman, 2010, p. 2). Universities with online-courses range from relatively new for-profits such as the University of Phoenix, founded in 1976, to long-established, primarily campus-based institutions such as the University of Pennsylvania and Cornell University (Zylberberg, 2010; Cornell University). Some institutions that offer online courses do so at higher levels of cost-efficiency through the use of adjunct faculty, as does Rio Salado, an entirely online community college, or through dedicated, course-based mentors, as does Western Governors University (Auguste, et al, 2010, p.42). While online instruction is gaining momentum, it is not the only type of innovation leading to a more efficient output of graduates in the U.S. Southern New Hampshire University, a private four-year institution with a primarily OnCampus student body, has successfully emphasized timely completion of degrees. A one-and-a-half-year set of core classes that all students must take before selecting a major helps reduce the number of excess credits at graduation. Southern New Hampshire University's academic advisors and registrar's office utilize customer relationship management (CRM) technology and protocols in ensuring that each student is on the path to timely graduation (Auguste et al, 2010, pp. 39, 53). Because this paper introduces strategies of Brigham Young University-Idaho, a primarily campus-based university, and a model that shows trade-offs in cost and graduate production between OnCampus daytime course delivery and alternative course delivery methods, it is intended mainly for use by institutions of higher education that have substantial On-Campus instructional activities.

\section{THE GRADUATE FISHBONE}

A subcommittee of the Brigham Young University-Idaho Enrollment Expansion group used the same format as the Ishikawa fishbone diagram in producing a "Graduate Fishbone," which projects the marginal number of students served and graduates produced by utilization of the strategies listed above. Dr. Kaoru Ishikawa, who pioneered methods of quality management, used the format to identify causes of error, the final output in his model. Causes of error could be fixed, leading to a lower rate of error. (McCormick, 2002, p. 227; Boulton \& Pecht, 1995). The Graduate Fishbone identifies methods of instruction and major policies that affect the costs of and the number of students served and graduates produced by an institution of higher education. Policies can be changed and any of the types of instructional delivery increased, leading to desired changes in these outputs. Brigham Young University-Idaho attempts to maximize the numbers of graduates and students served (within enrollment caps) at a low net cost. Henry C. Eyring was the main developer of the "Graduate Fishbone." The model draws from prior Graduate Fishbone diagrams built by Clark Gilbert and Steven C. Wheelright during their time as Brigham Young University-Idaho administrators. Much of the accuracy of the current version of the "Graduate Fishbone" is due to the help of Professors Edwin Sexton and Craig Johnson of Brigham Young-University Idaho, as well as input from the Enrollment Expansion group, and data from individual administrative departments.

\section{OUTLINE OF THE BRIGHAM YOUNG UNIVERSITY-IDAHO GRADUATE FISHBONE}

*In the explanation, references are made to cell colors. While it is helpful to view the color coded version of the Graduate Fishbone, all necessary information to understand the black and white version is present. 
**For a complete description of the mechanics of the Graduate Fishbone, please see the electronic version of this paper.

The Graduate Fishbone flows from left to right. On the left side of the model are all of the types of course delivery at Brigham Young University-Idaho. In the "Fixed Resource" group are On-Campus daytime courses. In the "Scalable Resource" group are more innovative and cost-effective courses. Levers, highlighted in light blue, are methods that administrators have of increasing the number of student credit hour output. For example, Number of Evening/Saturday Students and Average Credits Taken per Evening/Saturday Student are both levers. The courses offered lead to a total student credit hour output. With that output, Brigham Young University-Idaho can serve a certain number of students per semester, shown in the middle orange box, and a certain number of students per year, shown in the right-most orange box. That right-most box also contains annual data. The bottom-middle of the model shows semester student and financial numbers, and the bottom-right shows annual student, graduate, and financial numbers. The Graduate Fishbone's purpose is to show the effect that pulling a lever has on those outputs. The levers on the far left of the model can increase the number of credit hours delivered. The levers on the far right of the model deal with retention of those credit hours towards graduation.

A spreadsheet entitled "Financial Model," which is accessible through a tab toward the bottom of the Excel workbook, contains the financial data upon which the numbers in the cost and budget boxes in the Graduate Fishbone are based. Those costs and revenues are not treated as adjustable, or as levers, in the Graduate Fishbone. An addition of any type of student, ceteris-paribus, comes with additional cost and revenue. Depending on which of those two is larger, the effect of that marginal student on Impact on Operating Budget can be negative or positive. The economies of scale assumptions inherent in the Financial Model are as follows:

1. For all types of instruction except for On-Track On-Campus, average cost is approximately equal to marginal cost per student. Therefore, economies of scale achievable by spreading fixed costs over increased production of credits are currently considered negligible for those types of instruction.

2. For On-Track On-Campus students, the cost of adding full-time-equivalent semester students in increments of 3,000 starting from the current level is composed solely of extra faculty salaries (if entailed in the growth strategy) and the per student marginal overhead rate. When the student growth exceeds the 3,000 increment of fixed cost equilibrium, fixed costs must be increased by $80 \%$ of the average cost-per-student at the inception of the Graduate Fishbone for the prior 3,000 additional students. For On-Track OnCampus students, economies of scale exist for increases within those 3,000 additional student windows because students can be added without requiring an increase in fixed costs.

Adding those 3,000 students at Brigham Young University-Idaho requires increased class size and/or average credits per FTE faculty, and not only FTE faculty. The portion of growth that comes from additional faculty is limited by excess office space. That's likely true at other institutions as well. To lighten the need for excess office space, some of the additional FTE faculty can be adjunct faculty, who would be able to share offices.

Back in the Graduate Fishbone worksheet, the purple "Cost-per-Graduate" box shows baseline and adjusted numbers for cost-per-graduate. Below the yellow "Impact on Operating Budget" and purple "Cost-per-Graduate" boxes are blue boxes that show change in total cost, total revenue, and impact on operating budget. Those numbers are derived from the Financial Model worksheet.

\section{ECONOMIES OF SCALE IN ON-TRACK ON-CAMPUS GROWTH}

Economies of scale in On-Campus On-Track growth at Brigham Young University-Idaho exist not only within the increments of growth that do not require increasing fixed resources, but beyond that because fixed resources only need to be increased for the additional students by a percentage of the original fixed-cost-per-student. That is due to the fact that the size of some buildings, in addition to the existing complement of many employee types, are sufficient beyond the point at which most fixed costs would need to be increased. Identifying that percentage of fixed costs that must be increased can reveal whether economies or diseconomies of scale exist at an institution for On-Campus growth that requires building. If, upon reaching the On-Campus student growth that 
requires increasing fixed costs, the marginal cost of the additional On-Track On-Campus students is less than the original average cost of all types of students, economies of scale exist. The marginal cost of serving those students depends on the percentage by which fixed costs must be increased to allow for their entrance. In the Graduate Fishbone for Brigham Young University-Idaho, the percentage of total cost per student that must increase after reaching the Fixed Cost Equilibrium increment is estimated to be $80 \%$. With that estimate there are economies of scale even after building new facilities. However, if that percentage were $95 \%$, there would be diseconomies of scale. Below are two charts that show that effect. Further research could be done to identify more precisely the "Fixed Cost Increase Factor" at Brigham Young University-Idaho and other institutions. Although growth in OnTrack On-Campus students, in some cases, will not require faculty hires, due to uncertainty we have applied faculty salary per student across the graph and therefore our cost estimates are high.

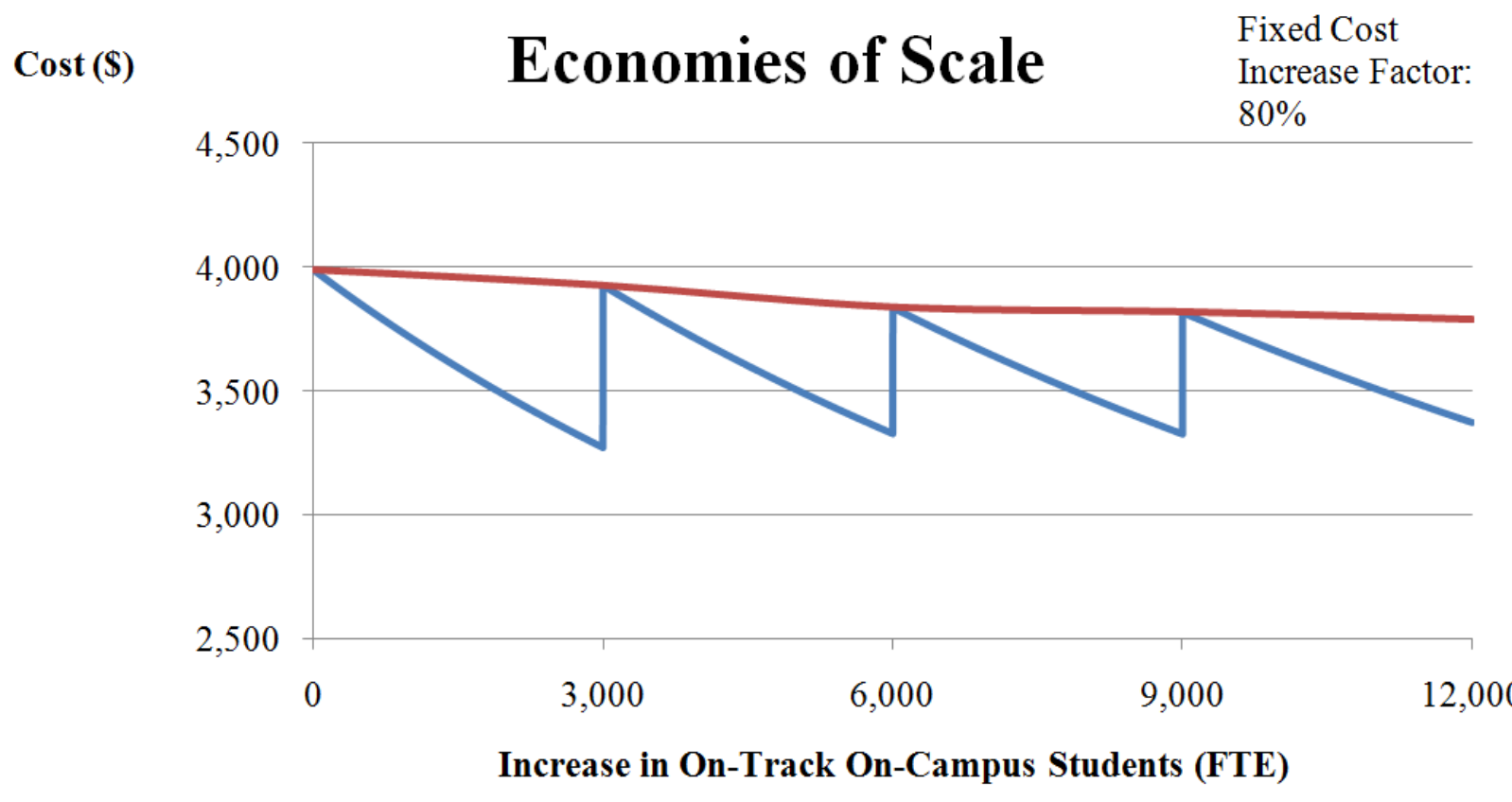

Semester Average Cost-Per-Student (FTE) 


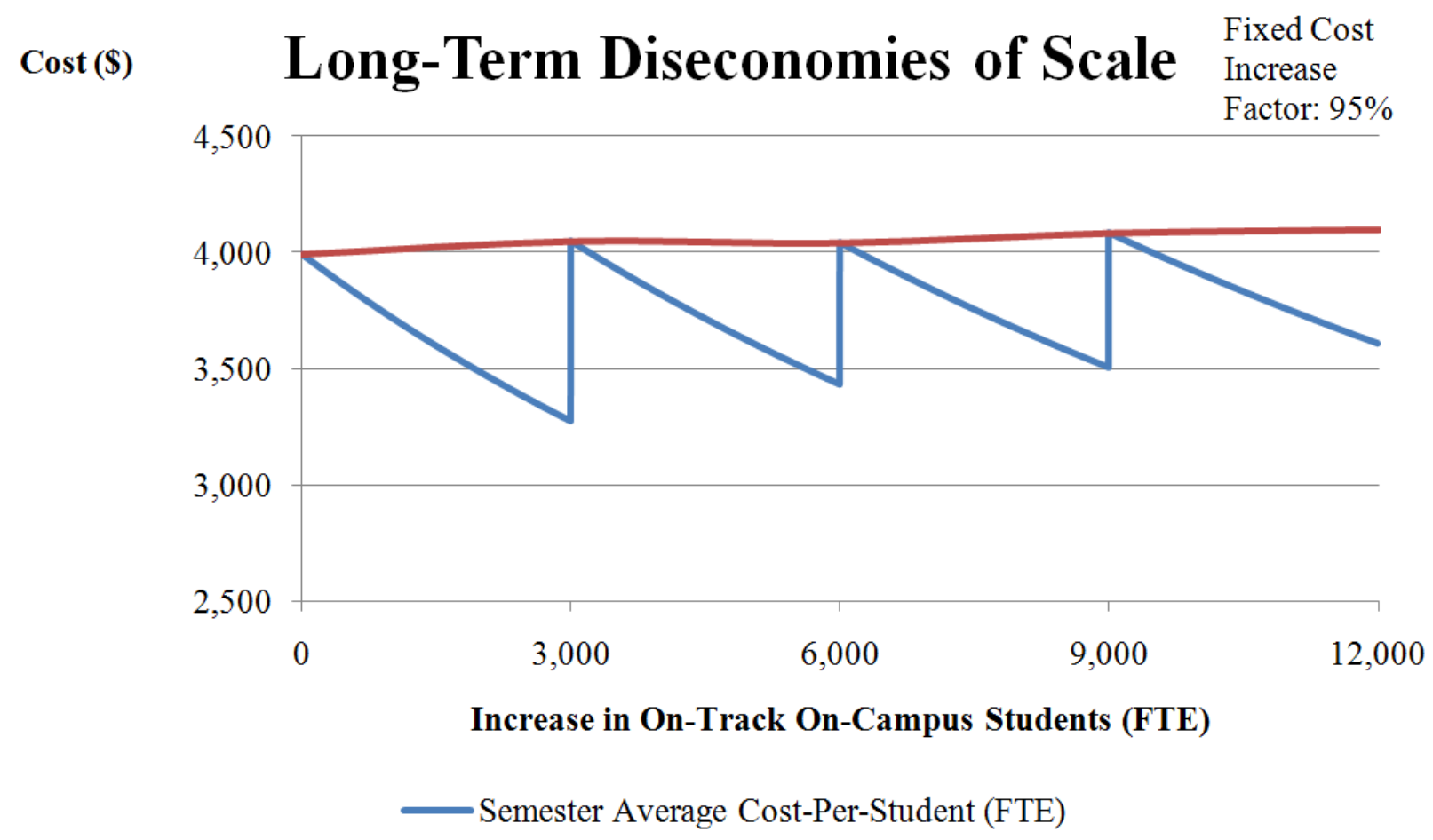

\section{BRIGHAM YOUNG UNIVERSITY-IDAHO GRADUATE FISHBONE DATA SOURCES}

*All data is from the 2010/2011 academic year

\section{Fixed Resource SCH}

- $\quad$ On-Campus faculty capacity and classroom capacity data were provided by the Brigham Young UniversityIdaho Academic Administration office.

\section{Scalable Resource SCH}

- $\quad$ Bachelor of University Studies (BUS), Special Session, and Off-Track data were provided by the Brigham Young University-Idaho Registrar's office.

- $\quad$ Pathway data is sourced from Brigham Young University-Idaho's Online Development office.

- $\quad$ Evening/Saturday data was provided by Brigham Young University Idaho's Continuing Education office.

- $\quad$ Transfer data and the current number for On-Track students were provided by Brigham Young UniversityIdaho's Enrollment office.

- $\quad \mathrm{AP}$ and Concurrent Enrollment data are notional, pending a report from Brigham Young University-Idaho's Registrar's office.

\section{Students Served and Graduation}

- $\quad$ Average credit hours at graduation and drop-out rate were provided by the Brigham Young UniversityIdaho's Academic Administration Office.

- $\quad$ Average credits-per-student data was provided by Brigham Young University-Idaho's Enrollment office. 


\section{Costs}

- Tuition data and estimates for the average cost of online instruction, Evening/Saturday, and Special Session were provided by Brigham Young University-Idaho's Continuing Education office.

- $\quad$ Tuition data and an estimate for the average cost of Pathway instruction, as well as tuition data for OnTrack, On-Campus courses were provided by Brigham Young University-Idaho's Academic Administration office.

- $\quad$ An estimate for the average cost of an On-Track On-Campus student was provided by Brigham Young University-Idaho's Budget office.

\section{EXPLANATION OF THE GENERIC GRADUATE FISHBONE}

Because many institutions have different operating policies and cost and revenue structures than those of Brigham Young University-Idaho, the version of the Graduate Fishbone used by Brigham Young University-Idaho administrators is not generally applicable without modification. For instance, an institution that operates for only two semesters a year would get only two-thirds of the projected increase in annual graduates from hiring an additional faculty member that Brigham Young University-Idaho would because of the difference between a two and three-semester calendar. For this reason, the author has produced a "Generic Graduate Fishbone" with policy assumptions more typical of other institutions. Hypothetical baseline numbers in that version approximate averages in American higher education. A given institution can replace those baseline numbers with its own to produce more accurate projections.

The Generic Graduate Fishbone differs only in its baseline data and in all intermediate equations that in the Brigham Young University-Idaho version apply a multiplier of 3 to convert "semester" to "annual"; the generic version applies a multiplier of 2, to represent the common academic calendar. Hypothetical baseline data are based on information from the Integrated Postsecondary Education Data System (U.S. Department of Education Institute of Educational Sciences), the reviewed literature, and Brigham Young University-Idaho data that are presumed to be consistent with like data from other institutions.

A summary profile of the hypothetical institution tracked in the Generic Graduate Fishbone follows. Annual: On-Campus Students - 24,423, Per Student Annual Tuition - $\$ 18,000$, Faculty $-1,000$, Average Faculty Salary - \$90,000, Classrooms - 250, Average Class Size - 40.

\section{UTILITY OF THE GRADUATE FISHBONE TO INSTITUTIONS OTHER THAN BRIGHAM YOUNG UNIVERSITY-IDAHO}

The Graduate Fishbone has informed strategic decisions made at Brigham Young University Idaho, and it may be similarly useful to other institutions. Even experienced higher education decision-makers may not have considered all of the growth levers in the model. The model can facilitate discussion of various strategies for influencing operating budget, cost-per-graduate, and graduate production, by showing the interrelatedness of these three outputs. By plugging their own institutional data into the model, decision-makers, can assess tradeoffs and forecast the effects of different management strategies.

While it is common to assume that reducing fiscal deficits in higher education inevitably means reducing the number of students served and the quality of their education, the Graduate Fishbone helps institutions identify deficit reducing strategies that may actually increase student and graduate volume without necessarily diminishing quality. Examples of scenarios that meet this standard immediately precede the conclusion. 

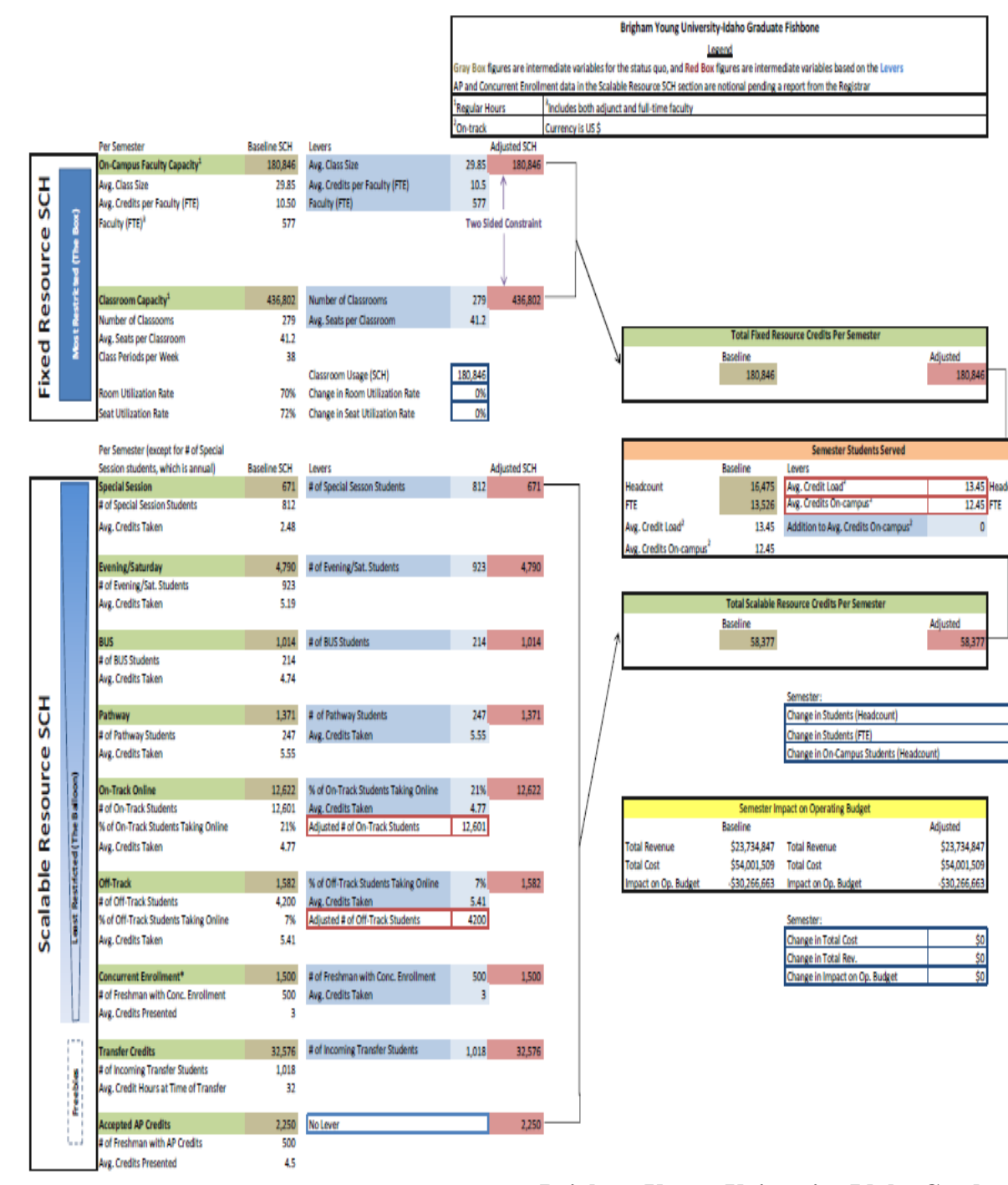
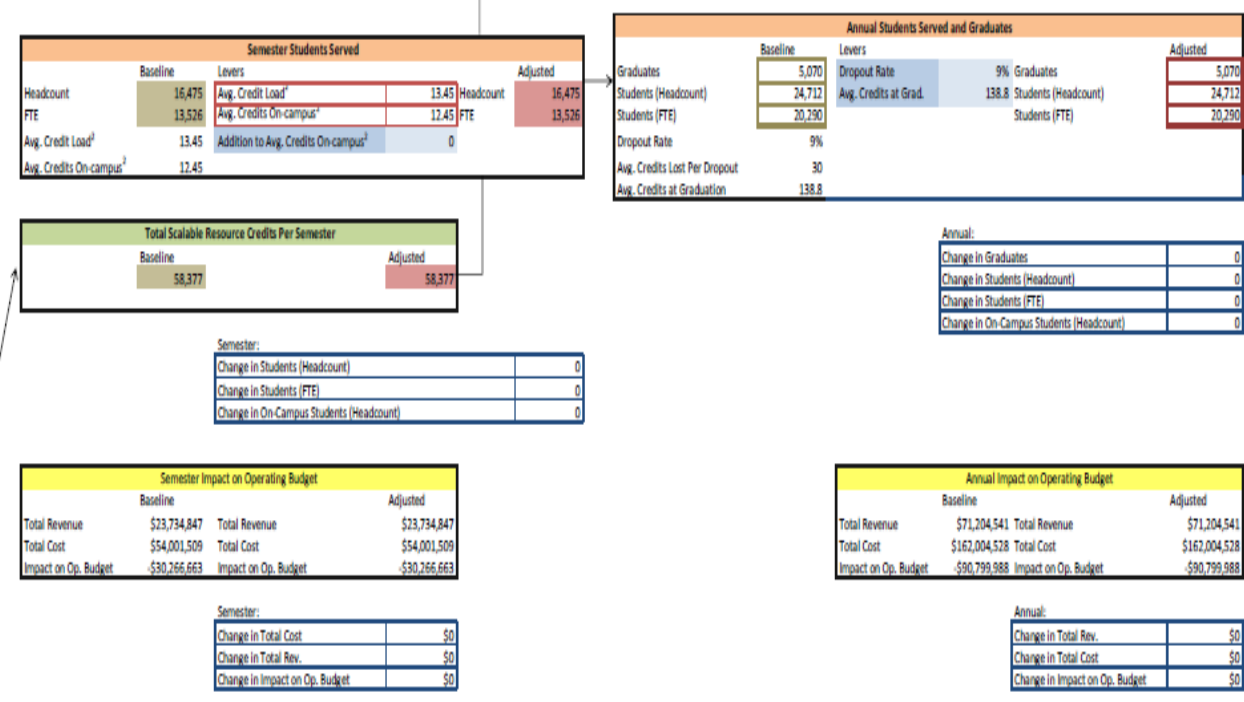

Brigham Young University-Idaho Graduate Fishbone 


\section{PROJECTIONS FOR GRADUATE FISHBONE OUTPUTS THAT ACCOUNT FOR UNCERTAINTY IN ADJUSTMENTS TO LEVERS}

The Graduate Fishbone shows the impact of pulling levers as though those operational decisions can be implemented with precision in a real institution. That, of course, is not the case. For example, an institution might hire new faculty in anticipation of enrolling more students but find that the students do not enroll as expected. Oracle's Crystal Ball software helps forecasters manage such uncertainties.

An example below is the prediction of Annual Students Served (FTE) in three years. Range goals, rather than exact values, for each lever are entered in the simulation setup. The 95\% confidence interval and probability distribution for Annual Students Served (FTE) after three years, based on the estimated lever ranges, follows.

Probability Distribution And Confidence Interval For Students (FTE)

\begin{tabular}{|l|}
\hline Forecast: FTE \\
\hline Summary: \\
\hline Certainty level is $95.000 \%$ \\
\hline Certainty range is from 13,655 to 14,988 \\
\hline Entire range is from 13,330 to 15,942 \\
\hline Base case is 13,526 \\
\hline After 25,000 trials, the std. error of the mean is 2 \\
\hline
\end{tabular}

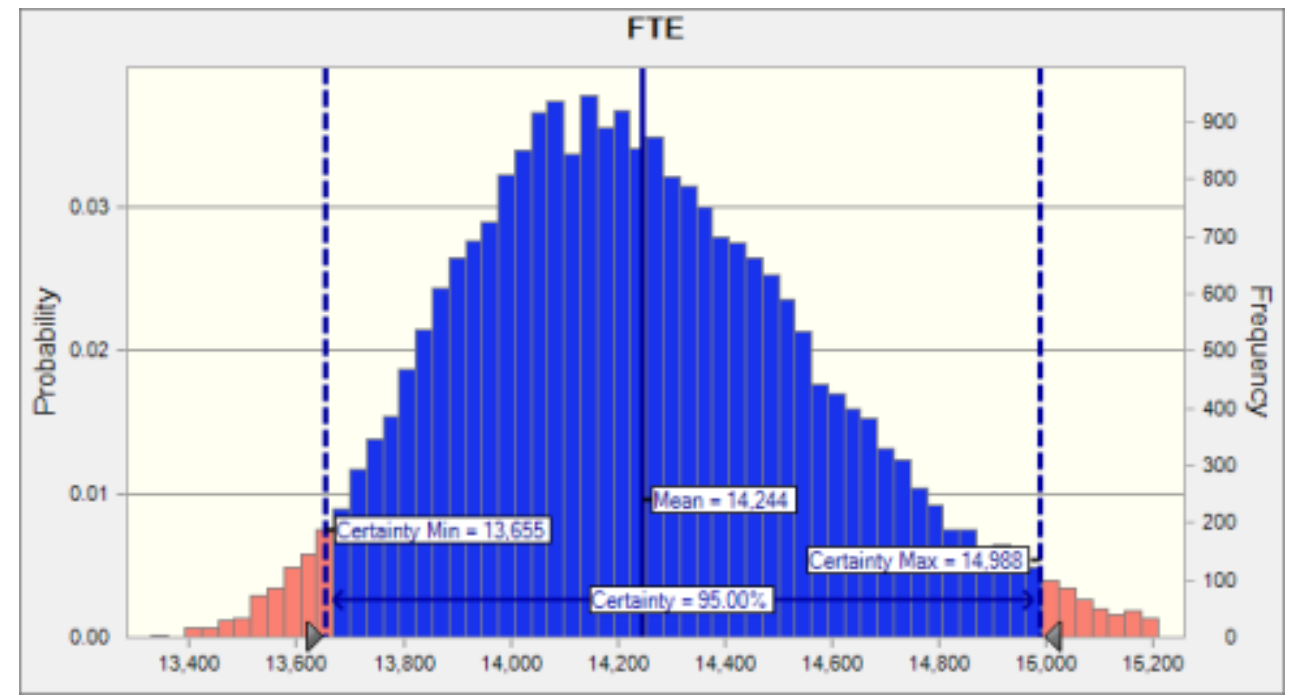

\section{PRIORITIZING LEVER ADJUSTMENT}

Crystal Ball analysis of the Graduate Fishbone shows the relative strength of levers in influencing student and financial outputs. The combination of the range of a lever and the multiplier effect as the value for a lever moves through the Graduate Fishbone determine the lever's strength. The lever ranges, or maximum amount by which each can be adjusted, are unique to each institution and must be entered as assumptions for an institutionspecific analysis. In order to become most efficient, an institution should prioritize the adjustment of levers that rank high in their ability to improve many outputs.

Below are charts that show the sensitivity of the outputs Graduates and Cost-per-Graduate, assuming Brigham Young University-Idaho's ability to adjust the levers. The assumptions are that levers in the Fixed 
Resource SCH section can increase by $5 \%$, while the flexibility and small baseline values for levers in the Scalable Resource SCH section allow some to increase by $30 \%$ and others by percentages up to $100 \%$. In the charts, sensitivity is defined as the percent of variance in the output that is attributable to the given lever. If the percentage is positive, the lever has a direct relationship to the output. If the percentage is negative, the lever has an inverse relationship to the output. The sensitivity chart for Impact on Operating Budget is included in the electronic version of this paper. Graduates are an output that an efficient school would want to maximize. Cost-per-Graduate is an output that an efficient school would want to minimize.

In the lever abbreviations, an "F" prefix indicates that the lever is from the Fixed Resource SCH section, and an "S" prefix indicates that the lever is from the Scalable Resource SCH section. The abbreviations are: \#TS= Number of Transfer Students $\mid \%$ OT OL $=\%$ On-Track Students Taking Online Courses $\mid$ ACF $=$ Average Credits per On-Campus Daytime Faculty $\mid$ ACG $=$ Average Credits at Graduation $\mid$ ACS OC $=$ Average Class Size OnCampus $\mid$ Faculty $($ FTE) $=$ On-Campus Daytime Faculty $($ FTE).
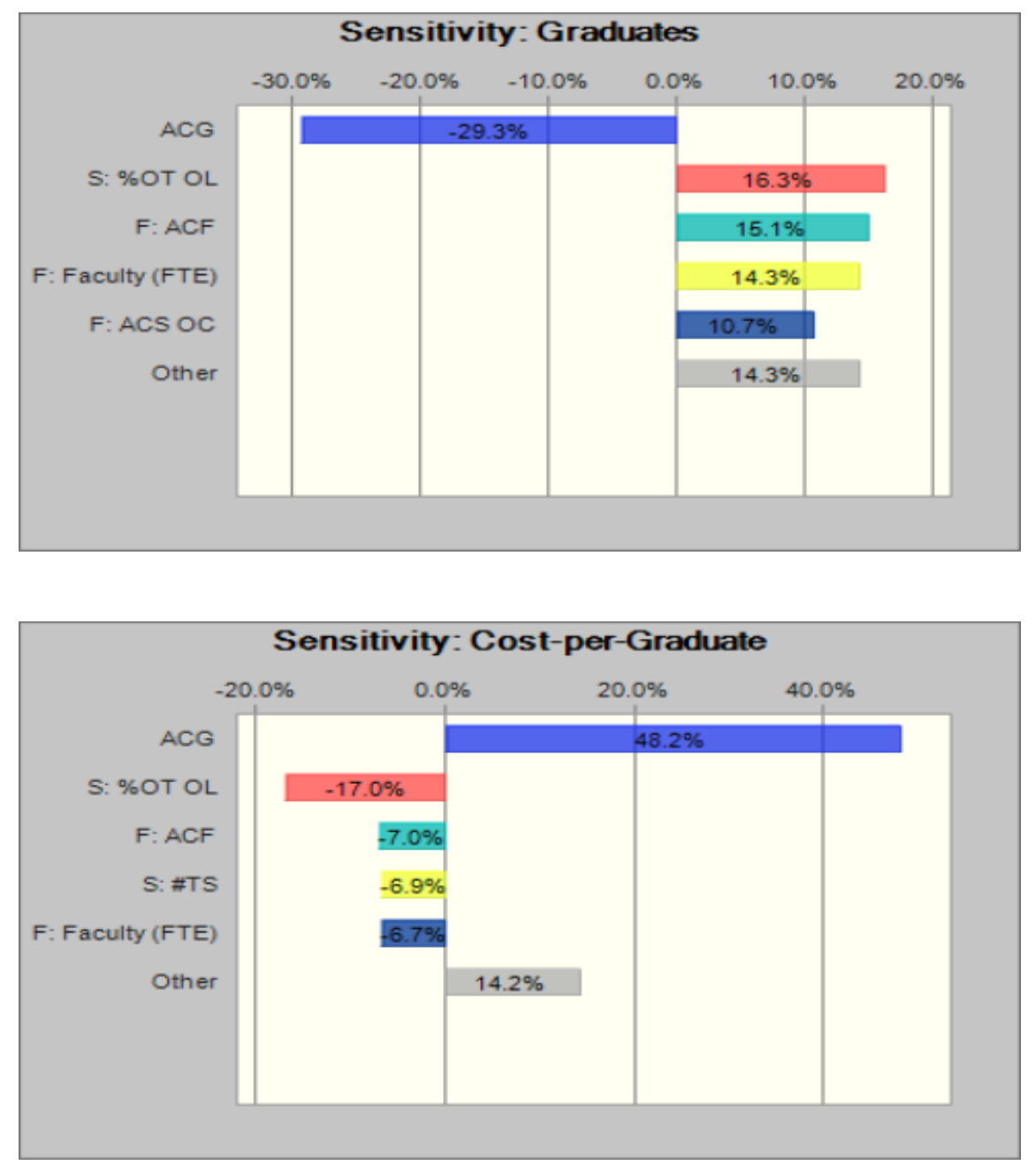

*The chart for Impact on Operating Budget is included only in the electronic version of this paper. Impact on Operating Budget is an output that an efficient institution of higher education would want to maximize. At extremes in growth that require building, levers in the Fixed Resource SCH section would be inversely related to Impact on Operating Budget.

Following is a ranking of the strength of levers in increasing overall efficiency at Brigham Young University-Idaho. The levers are ordered from greatest to least average contribution to variance in Graduates, Costper-Graduate, and Impact on Operating Budget. 


\section{Overall Efficiency}

1. $\%$ of On-Track Students Taking Online Courses

2. Average Credits at Graduation $\dagger$

3. Average Credits-per-Faculty

4. Faculty (FTE)

5. Average Class Size On-Campus

6. \# of Evening/Saturday Students

7. \# of Incoming Transfer Students

$\dagger$ Inversely related to improvement in overall efficiency

\section{OPTIONS FOR INCREASING COST-EFFICIENCY}

As mentioned previously, a cost-efficiency seeking institution could have one of many preferred approaches to achieving that efficiency. A range of representative options is shown below, with projected outputs from the Generic Graduate Fishbone. All of the options promote cost-efficiency in that they decrease cost-pergraduate and/or improve impact on operating budget. Significantly, the model shows that only the institutions that serve more students and produce more graduates are able to improve operating budget performance without reducing faculty. They can keep their On-Campus operations constant, increase output, and in so doing require less subsidization, so long as the growth is achieved through Scalable Resources. In general, cost-efficiency is achieved through maximizing the utilization of traditional campus resources and then increasing capacity through Scalable Resources.

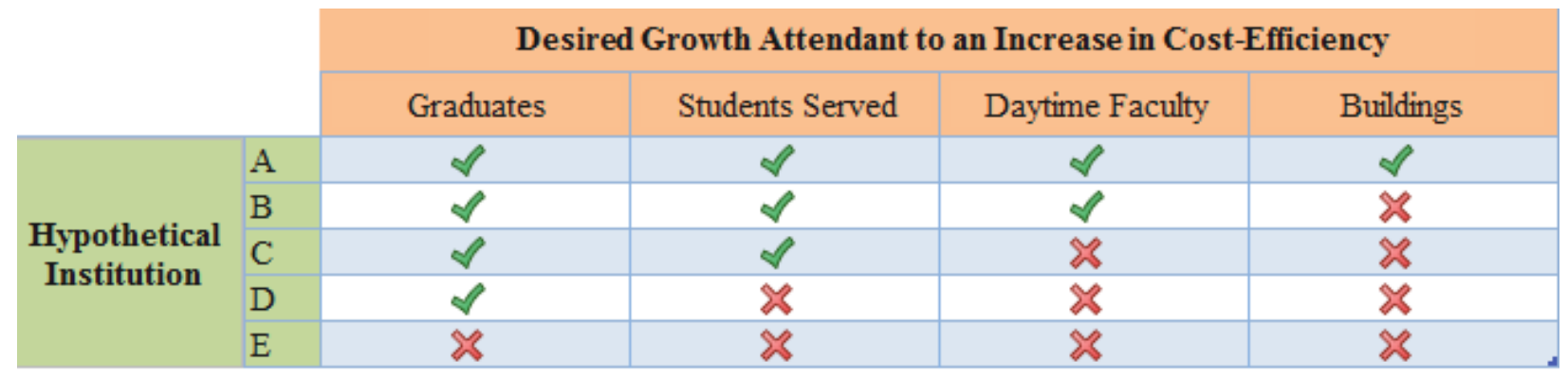

Institution A - Pursuing cost-efficiency that includes growth in graduates, students served, daytime faculty, and buildings:

- $\quad$ Institution A could add buildings and then maximize the utilization of traditional campus resources by adding more than 1, and as near to 2 times the Fixed Cost Equilibrium Increment of On-Campus FTE students as possible. For this example, the growth in On-Track On-Campus students is 3,399 FTE, well within 2 times the Fixed Cost Equilibrium Increment.

- $\quad$ To achieve that growth in FTE students, assume that Institution A adds 180 FTE faculty and also expands via Scalable Resources. For our example, Institution A adds 2,802 semester Evening/Saturday students (Headcount).

- $\quad$ Because Evening/Saturday is profitable, its growth mitigates the cost of expanding the campus. 


\begin{tabular}{|l|l|}
\multicolumn{2}{|l}{ Institution A Generic Graduate Fishbone Outputs } \\
\hline Annual: & 905 \\
\hline Change in Graduates & 6,724 \\
\hline Change in Students (Headcount) & 4,361 \\
\hline Change in Students (FTE) & 6,724 \\
\hline Change in On-Campus Students (Headcount) & $\$ 96,524,704$ \\
\hline Change in Total Revenue & $\$ 107,923,019$ \\
\hline Change in Total Cost & $-\$ 11,398,314$ \\
\hline Change in Impact on Operating Budget & $-\$ 2,439$ \\
\hline Change in Cost-per-Graduate & \\
\hline
\end{tabular}

Institution B - Pursuing cost-efficiency that includes growth in graduates, students served, and daytime faculty, but not buildings:

- Institution B could do the same as Institution A above, by adding faculty and adding 2,802 semester Evening/Saturday students (Headcount).

- $\quad$ However, to avoid the necessity to build, they must keep the On-Track On-Campus student growth number within the Fixed Cost Equilibrium Increment. For this example, they did so by adding 30 FTE faculty compared to the 180 that Institution A added. The additional growth in On-Track On-Campus students is 567 FTE, well within the Fixed Cost Equilibrium Increment.

Institution B Generic Graduate Fishbone Outputs

\begin{tabular}{|l|l|}
\hline Annual: & 317 \\
\hline Change in Graduates & 3,456 \\
\hline Change in Students (Headcount) & 1,529 \\
\hline Change in Students (FTE) & 3,456 \\
\hline Change in On-Campus Students (Headcount) & $\$ 44,948,051$ \\
\hline Change in Total Revenue & $\$ 12,454,014$ \\
\hline Change in Total Cost & $\$ 32,494,037$ \\
\hline Change in Impact on Operating Budget & $-\$ 5,963$ \\
\hline Change in Cost-per-Graduate & \\
\hline
\end{tabular}

Institution C - Pursuing growth that increases graduates and students served, but not daytime faculty or buildings:

- $\quad$ Institution C can avoid hiring daytime faculty by only expanding via Scalable Resources.

- $\quad$ For this example, it expands in the same way that Institutions A and B did, by adding 2,802 semester Evening/Saturday students (Headcount).

Institution C Generic Graduate Fishbone Outputs

\begin{tabular}{|l|l|}
\hline Annual: & 200 \\
\hline Change in Graduates & 2,802 \\
\hline Change in Students (Headcount) & 962 \\
\hline Change in Students (FTE) & 2,802 \\
\hline Change in On-Campus Students (Headcount) & $\$ 17,316,360$ \\
\hline Change in Total Revenue & $\$ 5,772,120$ \\
\hline Change in Total Cost & $\$ 11,544,240$ \\
\hline Change in Impact on Operating Budget & $-\$ 3,962$ \\
\hline Change in Cost-per-Graduate & \\
\hline
\end{tabular}


Institution D - Pursuing cost-efficiency that involves increased graduates, but not students served, daytime faculty, or buildings:

- Institution D can increase graduate output without increasing students served if retention is improved.

- $\quad$ For this example, Institution D lowers their average credits at graduation from 140 to 130 and lowers their dropout rate from $15 \%$ to $10 \%$

- $\quad$ This type of change is prudent in U.S. higher education, where only four in ten students graduate within six years (Johnson, Rochkind, Ott, \& DuPont, 2009). Decreasing the number of credits at graduation allows an institution to increase throughput. It does not require growth in the total number of students served each year. It is analogous to speeding up a production line that does not grow in size.

Institution D Generic Graduate Fishbone Outputs

\begin{tabular}{|l|l|}
\hline Annual: & 413 \\
\hline Change in Graduates & 0 \\
\hline Change in Students (Headcount) & 0 \\
\hline Change in Students (FTE) & 0 \\
\hline Change in On-Campus Students (Headcount) & $\$ 0$ \\
\hline Change in Total Revenue & $\$ 0$ \\
\hline Change in Total Cost & $\$ 0$ \\
\hline Change in Impact on Operating Budget & $-\$ 10,181$ \\
\hline Change in Cost-per-Graduate & \\
\hline
\end{tabular}

\section{CONCLUSION}

As White and Glickman observed, higher education in the U.S. has become a "mature industry," in the sense that it is oftentimes complacent with its current level of productivity (2007, p. 101). Policy makers and much of the American public, however, are not satisfied. They increasingly resist funding a system that lags behind those of other countries in delivering graduates. Institutions of higher education are unusual organizations in that they draw on a wide array of inputs to production and have disparate definitions of output. The complexity of these institutions makes it difficult to see means to decrease the cost of producing graduates. The graduate production fishbone illuminates those means and potentially assists institutions in increasing their efficiency.

As previously mentioned, one area for future research is to better define the economies of scale inherent in traditional campus growth. Another area for future research is determining cost-efficient growth initiatives in addition to the ones described above. Studies of other innovative institutions both in the United States and elsewhere could add to the range of potential options. In addition, new approaches might be modeled. For example, federal financial aid, currently available up to 180 credit hours, could be limited to 150 , as an incentive to better academic planning by students and institutions. Similar modeling might be done of graduated tuition, another potential incentive to expeditious graduation. Such policies might increase the graduate output of the U.S. system of higher education at low financial cost, though mechanisms would be needed to ensure learning quality.

\section{ABOUT THE AUTHOR}

Henry C. Eyring is 21 years old and is majoring in Economics at Brigham Young University-Idaho. He has completed internships at Tahitian Noni International (Tokyo), Leucadia National Corporation (Salt Lake City), and Innosight LLC (Boston). He currently serves on Brigham Young University-Idaho's Dean of Students Review Board, as a mentor for a scholarship program for students form disadvantaged backgrounds, on the board of the Newel K. Whitney Chapter of the Brigham Young University Management Society, and is a member of a Brigham Young University intramural swim team. He returned in fall 2010 from two years of full-time service as a missionary for the LDS church. Through that experience he developed an affinity for teaching. He also enjoys applied mathematics, and so plans on pursuing a Ph.D. in Economics and hopes to become a Business School professor. 


\section{REFERENCES}

1. Ranking Methodology. (2010). Retrieved 11 20, 2010, from Academic Rankings of World Universities: http://www.arwu.org/ARWUMethodology2009.jsp

2. Allen, I. E., \& Seaman, J. (2010). Class differences: online education in the united states. Babson Survey Research Group.

3. Auguste, B. G., Cota, A., Jayaram, K., \& Laboissiere, M. C. (2010). Winning by degrees: the strategies of highly productive higher-education institutions. New York: McKinsey \& Company.

4. Banchero, S. (2010, October 28). Tuition, pell grants rise in tandem. Retrieved December 13, 2010, from The Wall Street Journal: Digital Network: http://online.wsj.com/article/SB10001424052702303443904575578651983962836.html

5. Barro, R. J., \& Lee, J.-W. (2001). International data on educational attainment updates and implications. Oxford Economic Papers.

6. $\quad$ Boulton, W. R., \& Pecht, M. (1995). Quality Assurance and Reliability in the Japanese Electronics Industry. Retrieved November 21, 2010, from World Technology Evaluation Center: http://www.wtec.org/loyola/ep/c6s1.htm

7. Brigham Young University-Idaho Academic Administration. (2010). Catalog: Academic Calendar 20102011. Retrieved December 1, 2010, from Brigham Young University-Idaho: http://www.byui.edu/Catalog/2010-2011/Academic\%20Calendar.pdf

8. Brigham Young University-Idaho Activities Department. (2010). Activities Main Slide Deck. Rexburg, Idaho, USA.

9. Brigham Young University-Idaho Admissions. (2010). Admissions: Cost: Total Costs. Retrieved December 13, 2010, from Brigham Young University-Idaho: http://www.byui.edu/admissions/costs/totalcosts.shtml

10. Brigham Young University-Idaho Department of General Studies and University Studies. (2010). 20102011 Catalogue. Retrieved November 19, 2010, from Brigham Young University-Idaho: http://www.byui.edu/Catalog/2010-2011/General\%20Studies\%20\&\%20University\%20Studies.pdf

11. Cast Inc. (1999-2010). About UDL. Retrieved January 17, 2011, from Cast: http://www.cast.org/udl/index.html

12. Christensen, C. M., Johnson, C. W., \& Horn, M. B. (2008). Disrupting class: how disruptive innovation will change the way the world learns. McGraw Hill .

13. Ciciora, P. (2010, August 10). Higher education funding may need decade or longer to recover, scholar says. Retrieved December 4, 2010, from Illinois University News:

http://www.cnbc.com/id/36510805/The Worst 2011_State Budget_Gaps?

14. CNBC. (2010). The worst 2011 state budget gaps. Retrieved November 26, 2010, from CNBC: http://www.cnbc.com/id/36510805/The_Worst_2011_State_Budget_Gaps?

15. CNN Wire Staff. (2010, August 9). Retrieved November 28, 2010, from CNN:

http://articles.cnn.com/2010-08-09/politics/obama.education_1_graduation-rates-student-loan-educationsecretary-arne-duncan?_s=PM:POLITICS

16. Cornell University. (n.d.). Retrieved January 18, 2011, from eCornell: http://www.ecornell.com/

17. de Vise, D. (2011, March 8). State higher-ed funding at record low. Retrieved March 9, 2011, from Washington post: http://voices. washingtonpost.com/college-inc/2011/03/state highered funding at rec.html

18. Eyring, H. C., \& Callahan, R. H. (2008, September 24). Let disruption fix higher ed. Strategy and Innovation, 6(6).

19. Eyring, H. J., \& Christensen, C. M. (2010). The Innovative University: Changing the DNA from the Inside Out (Working Draft).

20. George Mason University. (2004, Spring). IRR Report. Retrieved December 3, 2010, from George Mason University: http://irr.gmu.edu/New/N_Persistence/PDFReport/Time2DegreeRpt07.pdf

21. GOP. (2010). A pledge to america: a new governing agenda based on the priorities of our nation, the principles we stand for, and america's founding values. Retrieved December 1, 2010, from GOP: http://pledge.gop.gov/resources/library/documents/solutions/a-pledge-to-america.pdf

22. Gorman, L. (n.d.). State education subsidies shift students to public universities. Retrieved December 2, 2010, from National Bureau of Economic Research: http://www.nber.org/digest/dec03/w9720.html 
23. Holland, M. (2011, February 27). The collision between medicaid and education. Retrieved March 9, 2011, from The deseret news: http://www.deseretnews.com/article/700113318/The-collision-between-educationand-Medicaid.html

24. Johnson, J., Rochkind, J., Ott, A. N., \& DuPont, S. (2009). With their whole lives ahead of them: myths and realities about why so many students fail to finish college. Public Agenda, New York.

25. Karlsson, S. (2010, March 13). U.S. national savings rate hits new low. Retrieved November 25, 2010, from Christian Science Monitor: http://www.csmonitor.com/Business/Stefan-Karlsson-sBlog/2010/0313/US-national-savings-rate-hits-new-low

26. Lee, J. M., \& Rawls, A. (2010). The college completion agenda 2010 report. College Board Advocacy and Policy Center.

27. McCormick, K. (2002). Quality. Butterworth-Heinemann.

28. McKinnon, J. D. (2010, January 27). A 'bleak' budget; but slightly better. Retrieved Dec. 12, 2010, from The Wall Street Journal: Digital Network: http://online.wsj.com/article/SB10001424052748703906204575026942464525862.html

29. Means, B., Toyama, Y., Murphey, R., Bakia, M., \& Jones, K. (2010). Evaluation of evidence-based practices in online learning: a meta-analysis and review of online learning studies. U.S. Department of Education, Office of Planning, Evaluation, and Policy Development . Washington D.C. : U.S. Department of Education .

30. Miller, C. (2008). The spellings commission report: the chair's perspective. Forum Futures.

31. Morris, D. (2008). Economies of scale and scope in e-learning. Studies in Higher Education, 33(3), 331343. doi:10.1080/03075070802066164.

32. Rosner, S. R., \& Shropshire, K. L. (2004). The Business of Sports. Jones and Bartlett Publishers.

33. Salmon, F. (2010, January 4). Chart of the day: negative net national savings. Retrieved December 13, 2010, from Reuters: http://blogs.reuters.com/felix-salmon/2010/01/04/chart-of-the-day-negative-netnational-savings/

34. Smith, W., \& Bender, T. (2008). American higher education transformed, 1940-2005: documenting the national discourse. Baltimore: Johns Hopkins University Press.

35. The Carnegie Foundation. (n.d.). Classification Description: Graduate Instructional Program Classification. Retrieved November 23, 2010, from The Carnegie Foundation for the Advancement of Teaching: http://classifications.carnegiefoundation.org/descriptions/grad_program.php

36. The Princeton Review. (n.d.). Best Value College Methodology. Retrieved December 6, 2010, from The Princeton Review: http://www.princetonreview.com/bvc-methodology.aspx

37. U.S. Department of Education. (2006). A test of leadership: charting the future of U.S. higher education. Washington D.C. .

38. U.S. Department of Education Institute of Educational Sciences. (n.d.). Retrieved January 25, 2011, from National center for education statistics: http://nces.ed.gov/fastfacts/index.asp?faq=FFOption6\#faqFFOption6

39. White, S. C., \& Glickman, T. S. (2007). Innovation in higher education: Implications for the future. New Directions for Higher Education, (137), 97-105. doi:10.1002/he

40. Willis, B. (2009, August 1). U.S. recession worst since great depression, revised data show. Retrieved Nov. 24, 2010 , from Bloomberg: http://www.bloomberg.com/apps/news?pid=newsarchive\&sid=aNivTjr852TI

41. Zylberberg, N. (2010, February 15). Online courses becoming a growing national trend. The Daily Pennsylvanian. 